\title{
Biological and Chemical Redox Transformations of Mercury in Fresh and Salt Waters of the High Arctic during Spring and Summer
}

\author{
A LEX A N DR E J. POU L A IN, E DENISEGARCIA, ${ }^{M}$ A R C A M Y OT,PETER G.C.CAMPB ELL, F A R H A D R \\ A O F IE, A N P A R IS A A. A R I Y A \\ Groupe de Recherche Inter-universitaire en limnologie (GRIL), Département des sciences biologiques, Université de Montréal, \\ C.P. 6128, Succursale Centre-Ville, Pavillon Marie-Victorin, Montréal, Québec, Canada, H3C 3J7, Université du Québec, INRS- \\ Eau, Terre et Environnement, 490 de la Couronne, Québec, QC, Canada G1K 9A9, and Department of Chemistry, and \\ Department of Atmospheric and Oceanic Sciences, McGill University, 801 Sherbrooke Street West, Montréal, Quebec, Canada \\ H3A 2 K6
}

It is well-established that atmospheric deposition transports $\mathrm{Hg}$ to Arctic regions, but the postdepositional dynamicsofHgthatcanalteritsimpact onArcticfoodchains areless understood. Throughaseries of in situexperiments, we investigated the redox transformations of $\mathrm{Hg}$ in coastal and inlandaquatic systems. During spring and summer,Hg reduction in streams and pond waters decreased acrossa4-foldincreasein salinity. This alteration of $\mathrm{Hg}$ reduction due to chloride was counterbalanced by the presence of particles, whichfavored the conversion of oxidizedHgtoits elementalform.Insalinewaters, biogenic organic materials, produced by algae, were able to promote oxidation of $\mathrm{Hg}(0)$ even underdark conditions.Overall these results point to the vulnerability of marine/ coastal Arctic systems to $\mathrm{Hg}$, compared to inland systems, with oxidation processes enhancing $\mathrm{Hg}$ residence times andthusincreasingitspotentialtoenterthefoodchain.

\section{Introduction}

The discovery of mercury depletion events (MDE) in polar areas (1-4), resulting in rapid, near complete depletion of $\mathrm{Hg}$ from the atmosphere, provides evidence that atmospheric oxidation of $\mathrm{Hg}$ is faster than initially proposed (5). These oxidation processes are thought to occur in marine- influenced environments (6), and to involve reactive halogen radicals from sea-salt aerosols (2). Recent studies have shown that $\mathrm{Br}$ and $\mathrm{BrO}$ radicals are the most effective halogens driving $\mathrm{Hg}(0)$ oxidation (7). Modeling studies of atmospheric transport of $\mathrm{Hg}$ originating from Asia, Europe and, to a lesser extent, North America, to higher latitudes, combined with the rapid depletion of atmospheric $\mathrm{Hg}(0)$, suggest that the Arctic is a sink for $\mathrm{Hg}(8)$. These episodes of $\mathrm{Hg}$ deposition can pose a serious threat to Arctic ecosystems as evidence suggests that newly deposited Hg may be highly bioavailable (2). In temperate areas, experiments have linked inorganic $\mathrm{Hg}$ in atmospheric deposition to $\mathrm{Hg}$ levels in fish $(9,10)$, while in Arctic regions, increases in mercury contamination of the Arctic food chain (11) and increased levels of mercury exposure in indigenous populations (12) have been documented. In order to better assess the magnitude of the Hg available to the food chain, however, we must first characterize the fate of the newly deposited $\mathrm{Hg}$.

So far most of the work on the redox cycling of $\mathrm{Hg}$ in Subarctic and high Arctic regions has focused on $\mathrm{Hg}$ dynamics in the atmosphere and in snow $(2,4,13-16)$, as well as in freshwater lakes $(17,18)$; to our knowledge, very few studies have dealt with Arctic coastal and marine waters (19). Since recent studies from temperate regions suggest that $\mathrm{Hg}(0)$ photooxidation is favored in the presence of chloride $(20,21)$, and because MDE have been reported to occur under marine influence, it is critical to better assess the postdepositional dynamics of $\mathrm{Hg}$ in these higher salinity environments. Only a few studies in Subarctic and Arctic environments have focused on the importance of $\mathrm{Hg}$ redox reactions during the snowmelt period $(2,22)$ or in lakes during summer (23). Despite their prevalence in the Arctic landscape, no data on $\mathrm{Hg}$ currently exist for ponds and streams during the summer, a period during which biological production is high.

Despite the harsh conditions that prevail for most of the year in polar areas, microorganisms such as algae or bacteria can thrive during the very short Arctic summer. Whereas studies in temperate areas have highlighted the role of microorganisms in the $\mathrm{Hg}$ redox cycle (24-27), no study to date has focused on their involvement in $\mathrm{Hg}$ cycling in polar areas.

The purpose of this research was (i) to assess the significance of photomediated redox processes in the Arctic Hg cycle in fresh and brackish ponds and streams as well as in saltwaters; (ii) to evaluate the environmental variables affecting this redox cycling (e.g., $\left[\mathrm{Cl}^{-}\right]$, particles, $[\mathrm{Fe}]$ ); and (iii) to determine the importance of algal and microbial mats in this cycle.

\section{Experimental Section}

Sampling Sites. The Hg redox cycle was assessed over a wide range of salinities on Cornwallis Island. Water types chosen to carry out our incubation experiments were water obtained from the following: (i) snowmelt $0.06<\left[\mathrm{Cl}^{-}\right]<0.11$ mmol, $\left.\mathrm{L}^{-1}\right)$; (ii) freshwater ponds and streams $\left(0.11<\left[\mathrm{Cl}^{-}\right]<1.61 \mathrm{mmol}, \mathrm{L}^{-1}\right)$; (iii) brackish and salt ponds, usually located in coastal areas or directly on the sea-ice when connected to underlying water $\left(12<\left[\mathrm{Cl}^{-}\right]<26 \mathrm{mmol}, \mathrm{L}-1\right)$; and (iv) coastal seawater, with the highest salinity we encountered $\left(\left[\mathrm{Cl}^{-}\right]=517 \mathrm{mmol}, \mathrm{L}^{-1}\right)$. Sampling sites locations and their detailed water chemistry are presented in supplementary Figure 1 and Table 1 in the Supporting Information. 


\section{https://pubs.acs.org/doi/abs/10.1021/es061980b}

SamplingProcedure. All containers used for $\mathrm{Hg}$ sampling and analysis were acid-washed and thoroughly rinsed with milliQ water $(R>18.2 \mathrm{M} \Omega \cdot \mathrm{cm})$. Clean techniques were used and nonpowdered gloves were worn at all times to avoid contamination. Surface water for total $\mathrm{Hg}$ analysis ( $\mathrm{THg}$ ) was sampled in triplicate using $250 \mathrm{~mL}$ Teflon FEP bottles, and rinsed three times with natural water prior to collection. All samples were kept in the dark and at $4{ }^{\circ} \mathrm{C} \pm 2{ }^{\circ} \mathrm{C}$ until analysis. In order to carry out some incubation experiments, water was collected in the field in quartz bottles and additional water samples were collected using 20 L Teflon (PFA) sampling bags.

Incubations. Incubations were carried out between June 20 and July 25, 2004. During this period, after snowmelt began, daily air temperatures averaged ca. ${ }^{\circ} \mathrm{C}$; the maximum and minimum air temperatures were $8.6{ }^{\circ} \mathrm{C}$ and $-2.2{ }^{\circ} \mathrm{C}$, respectively. Incubation experiments were carried out using $500 \mathrm{~mL}$ quartz bottles, filled directly in the field or from a Teflon bag shortly after collection. Incubation vessels were exposed to outside environmental conditions and were subjected to various treatments including filtration or the addition of a metabolic inhibitor. Alternative treatments involved either the addition of whole living microorganisms such as algae or microbial mats, or the addition of their exudates, i.e., dissolved biogenic compounds. During incubation, bottles were placed horizontally with their caps pointing north. Incubations lasted between 3 and $8 \mathrm{~h}$ and were initiated before noon. Two types of incubation were undertaken: (i) time series experiments in which one sample for each treatment was collected and analyzed immediately for dissolved gaseous mercury, typically after the first $30 \mathrm{~min}$, and subsequently every hour until a plateau was reached; and (ii) experiments where bottles were exposed for a predefined period of time and triplicate samples were analyzed at the beginning and at the end of the incubation period. Note that contrary to other studies (28), we carried out batch incubation experiments. Dark controls were obtained by incubating reaction vessels in the field, either wrapped in aluminum foil or kept in opaque black bags. Filtration was performed by gently pumping out water from the sampling bag, using $0.45 \mu \mathrm{m}$ in-line glass fiber filters (Whatman). Prior to use, filters were acid-washed $\left(\mathrm{HNO}_{3} ; 10 \%\right)$, thoroughly rinsed with milliQ water, and then rinsed with sampling water. Please see incubation section in Supporting Information for details on how the exudates and whole cells components were derived.

Importance of Reduction and Oxidation Reactions. We used the variations in dissolved gaseous mercury (DGM) concentrations between the beginning and end of incubation experiments $\left(\Delta_{\mathrm{DGM}}\right)$, normalized for the amount of light received when a plateau was reached and expressed in fmol $\cdot \mathrm{L}^{-1} \mathrm{~mol}_{\text {photon }}{ }^{-1} \cdot \mathrm{m}^{2}$, as a proxy for the amount of photoreducible Hg. This normalization allowed acomparison between different days and different treatments.

To assess the dark oxidation of newly produced DGM, we assumed pseudo first-order kinetics, described by the following equation:

$$
\ln \left(\frac{[H g(0)]_{t}}{[H g(0)]_{0}}\right)=-k t
$$

where $[\mathrm{Hg}(0)]_{\mathrm{t}}$ and $[\mathrm{Hg}(0)]_{0}$ represent DGM concentrations at time $t$ and at the beginning of the incubations, respectively; $k$ is the apparent rate of oxidation of $\operatorname{Hg}(0)$ and corresponds, in absolute value, to the slope of the regression of $\ln \left([\mathrm{Hg}(0)]_{t} /[\mathrm{Hg}(0)]_{0}\right)$ versus $t$. We assumed the concentration of oxidizing agent to be in excess and $\mathrm{Hg}(\mathrm{II})$ reduction to be insignificant in the dark.

Chemical Analysis. To minimize losses of DGM during the analysis as well as $\mathrm{Hg}^{0}$ carryover between samples, water was sparged directly in the quartz incubation bottle. We used a zero-air generator (Tekran model 1100) to sparge the sample at a flow rate of $1.5 \mathrm{~L} \cdot \mathrm{min}^{-1}$ and at room temperature. The bottle was connected to an automated atmospheric mercury analyzer (Tekran model 2537) to monitor the decrease of DGM over time (one reading every $5 \mathrm{~min}$ ). The sparging step was stopped when $\mathrm{Hg}$ concentrations declined to nondetectable values. The working detection limit of this method is usually $<0.01 \mathrm{pmol} \cdot \mathrm{L}^{-1}$, but in the field we calculated it as $0.03 \mathrm{pmol} \cdot \mathrm{L}^{-1}$ or three times the standard deviation of ten system blanks run on water with low Hg levels $\left(\mathrm{THg}<0.3 \mathrm{pmol} \cdot \mathrm{L}^{-1} ; R>18.2 \mathrm{M} \Omega \bullet \mathrm{cm}\right)$. Triplicates were regularly analyzed and typically varied between 1 and $9 \%$, although some turbid samples varied by up to $20 \%$ (median $=8.8 \%$ ).

Total Hg concentrations in snow and water were quantified using the method described by Gill and Bruland (29), using a mercury fluorescence detector (Tekran Model 2500) and sodium borohydride as a strong reducing agent. The working detection limit of this method was calculated as $0.45 \mathrm{pmol} \cdot \mathrm{L}^{-1}$ or three times the standard deviation of ten procedural blanks. Triplicates were systematically analyzed and typically varied between 0.5 and $10 \%$ and up to $20 \%$ for some very turbid samples $($ median $=8.4 \%)$

Organic compounds in surface snow were analyzed using two different methods: (a) electron spray ionization mass spectrometry (ESI-MS); and (b) solid-phase micro-extraction (SPME) followed by gas chromatography-mass spectrometry (GCMS) analysis (see analyses of organic compounds section in Supporting Information for details).

Modeling Dissolved Inorganic Hg Speciation. To assess the inorganic speciation of $\mathrm{Hg}$, we used a chemical equilibrium program (MINEQL+, version 4.5) (30). Stability constants used in the model are presented in Table 2 in the Supporting Information. These constants were corrected for the ionic strength of the sample, as calculated by the model. We do not present the complexation of $\mathrm{Hg}$ with dissolved organic matter (DOM) due to the current lack of consensus regarding binding constants for $\mathrm{Hg}-\mathrm{DOM}$ complexation reactions. We report here inorganic $\mathrm{Hg}$ speciation since inorganic species are presumed by most authors to be more reactive and more easily reduced (31) than organically complexed species, and because inorganic neutrally charged species are likely more bioavailable than those species bound to organic matter. It is important to note that characterization 
of natural organic matter, especially with respect to the moieties with which $\mathrm{Hg}$ is most likely to bind (e.g., $\mathrm{R}-\mathrm{SH}$ ), is essential to adequately model $\mathrm{Hg}$ speciation. To the best of our knowledge, no true thermodynamic $\mathrm{Hg}-\mathrm{DOC}$ binding constants have been reported for organic matter originating from polar environments and conditional constants obtained in other systems are not directly applicable, especially since they exhibit great variability (32). Note that the addition of small organic molecules known to be present in Arctic snow (acetate and formate) did not change theinorganic speciation of $\mathrm{Hg}$ presented here.

\section{Results and Discussion}

Influence of Abiotic Variables on DGM Production. We assessed DGM production through incubation experiments at sites representing a salinity gradient on Cornwallis Island. Chloride concentrations at these sites covered 4 orders of magnitude from $5 \times 10^{-5} \mathrm{~mol} \cdot \mathrm{L}^{-1}$ for flowing meltwaters to $0.5 \mathrm{~mol} \cdot \mathrm{L}^{-1}$ for coastal seawater (see Table 1 in the SI). We observed a strong decline in DGM production corrected for incoming radiation ( $\triangle \mathrm{DGM}$ ) with increasing chloride levels (Figure 1). This decline was not correlated to changes in total $\mathrm{Hg}$ levels or DOC concentrations, but corresponded to an increase in the relative importance of chlorocomplexes and particulate $\mathrm{Hg}$, concomitant with a decrease in the relative abundance of $\mathrm{Hg}(\mathrm{OH})_{2}(\mathrm{Figure}$ 2). DGM photoproduction and total iron concentrations were not related in freshwater systems, but were positively and significantly related in systems connected to seawater ( $r=0.96, p=0.0017, n=5$ inset in Figure 1).

DGM production observed in June, at $\left[\mathrm{Cl}^{-}\right]<0.1 \mathrm{mmol} \cdot \mathrm{L}^{-1}$, was higher $\left(\right.$ mean $=250 \mathrm{fmol} \cdot \mathrm{L}^{-1} \mathrm{~mol}_{\text {photon }}{ }^{-1} \cdot \mathrm{m}^{2}$ than any yet reported in unamended waters from temperate areas $(33-35)$. The Arctic experiences fast depletion of atmospheric mercury during early springtime, increasing the pool of $\mathrm{THg}$ in surface snow (36) and possibly that of highly reactive species (2). Although earlier studies showed that important photoinduced emissions of DGM were observed

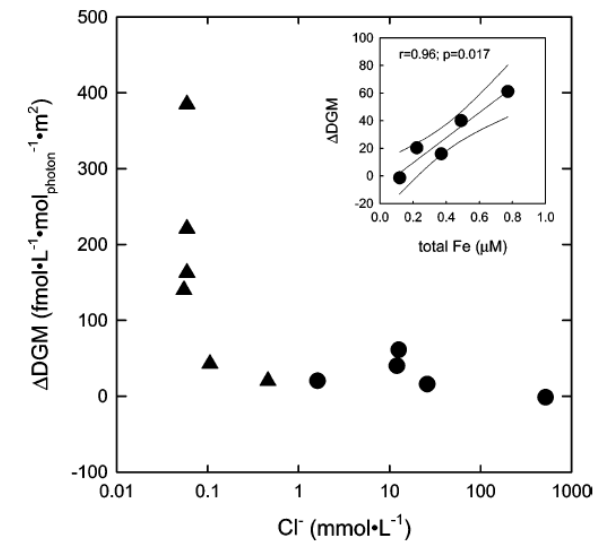

FIGURE 1. Distribution of in situ DGM production as determined over a gradient of chloride concentrations, normalized for the amount of light received. Triangles represent freshwater sites; circles represent coastal sites connected to seawater. Inset shows the relationship between total Fe and DGM production in sites connected relationship betwion theawate there is a significant relationship between DGM production and
$\left[\mathrm{Cl}^{-}\right] \log \left(\Delta_{\mathrm{DGM}}\right)=1.65-0.46 \times \log \left[\mathrm{Cl}^{-}\right], n=11, p=0.0012, r^{2}=0.70$.

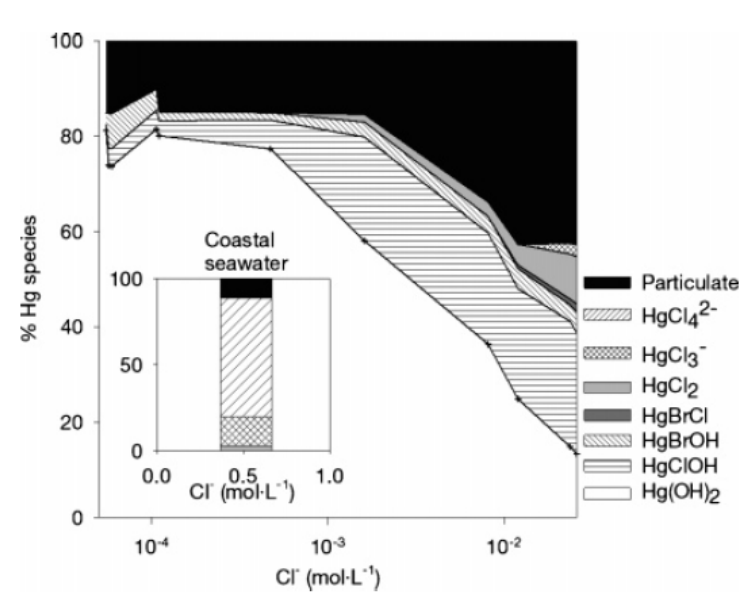

FIGURE 2. Modeling of inorganic $\mathrm{Hg}$ speciation over a chloride gradient. Inset represents the calculated speciation of inorganic $\mathrm{Hg}$ in coastal seawater. Each cross represents a sampling site (see Table 1 in the Supporting Information for detailed water chemistry).

during the late spring period $(2,22)$, it is likely that some reactive species are trapped within the snowpack, protected from incoming radiation, and are released upon snowmelt, contributing to the high rates of reduction observed.

Earlier studies showed that $\mathrm{Hg}^{0}$ oxidation is enhanced in the presence of chloride and organic matter $(20,37)$, and that chloride may participate to the formation of poorly reducible $\mathrm{Hg}$ complexes (38). Lalonde et al. (37) also observed that pre-filtration decreased $\mathrm{Hg}^{0}$ production in temperate brackish systems. To further explore the mechanisms in- volved in DGM production we carried out a series of experiments in which particles were removed by filtration at both low and high chloride concentrations.

Consistently, sites exhibiting the highest chloride concentrations experienced a decrease in DGM photoproduction upon filtration, ranging from $50 \%$ in a lagoon system (Figure 3A) to ca. 100\% in a salt pond over sea ice (Figure 3B). Filtration caused a decrease for $\left[\mathrm{THg}\right.$ ( from $8.4 \pm 0.7$ to $5.0 \pm 0.1 \mathrm{pmol} \cdot \mathrm{L}^{-1}$ ) and $\left[\mathrm{TFe}\right.$ (from $0.11 \pm 0.02$ to $0.02 \pm 0.01 \mu \mathrm{mol} \cdot \mathrm{L}^{-1}$ ) (Figure $3 \mathrm{C}$ ). No DGM production was observed in either unfiltered or filtered samples kept in the dark (e.g., Figure 3B).

In freshwater systems, the photoproduction of DGM was similar regardless of whether particles smaller than $0.45 \mu \mathrm{m}$ were removed (Figure 3D). No significant differences were observed between $[\mathrm{THg}]$ in unfiltered $\left(4.1 \pm 0.9 \mathrm{pmol}, \mathrm{L}^{-1}\right)$ and filtered samples $\left(3.5 \pm 0.3 \mathrm{pmol} \cdot \mathrm{L}^{-1}\right)$. Inorganic $\mathrm{Hg}$ speciation was largely dominated by uncharged hydroxo-complexes (Figure 2).

The decrease of $\Delta_{\mathrm{DGM}}$ in coastal areas upon filtration suggests that heterogeneous reactions may be involved. Indeed, filtration 
substantially decreased $[\mathrm{THg}]$ and [Fe], especially in brackish and saltwaters. Although previous studies have indicated that Hg photoreduction can result from heterogeneous processes $(37,39,40)$, the nature of the particles involved has not yet been

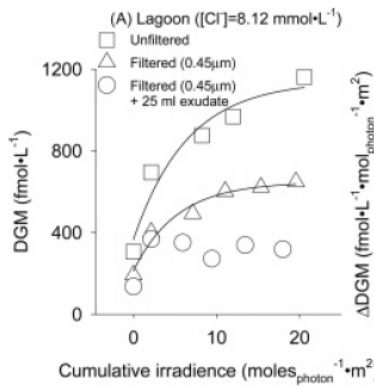

(B) Salt pond $\left([\mathrm{Cl}]=25.9 \mathrm{mmol}^{\left.-L^{-1}\right)}\right.$

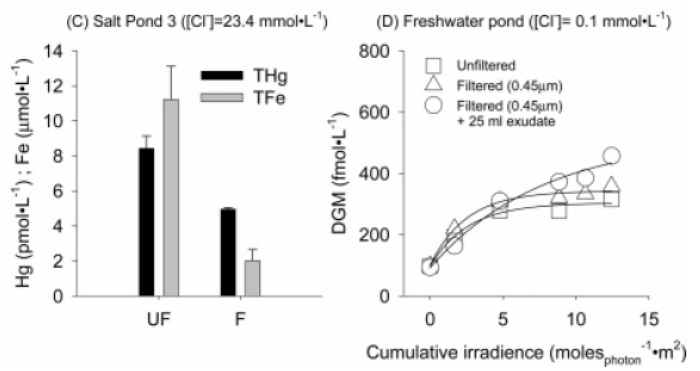

FIGURE 3. (A) Times series incubation showing the evolution of [DGM] as a function of the cumulative amount of PAR received during the incubation period in water that was unfiltered, filtered, or filtered but amended with exudates from a microbial and algae consortium collected in the lagoon. (B) DGM production in a pond over sea ice in unfiltered (UF) or filtered (F) samples, exposed under natural sunlight or kept in the dark. (C) Total $\mathrm{Hg}$ and total iron concentrations in unfiltered or filtered saline water from a pond over sea ice. (D) Time series incubation showing the evolution of [DGM] as a function of the cumulative amount of PAR received during the incubation period in water that was unfiltered, filtered, or filtered but amended with exudates from microbial and algae consortium collected in a freshwater inland pond.

described. Analysis of the particles present in both salt and freshwater incubations revealed the presence of iron oxides among sand grains, aluminosilicates, clays, and calcium carbonate deposits (see elemental composition of particles in Supporting Information for details). Previous studies have suggested that the iron redox cycle is partly controlled by light $(41,44)$, and that it is involved in the $\mathrm{Hg}$ redox cycle of freshwaters through the formation of highly reducing free radicals (42). Furthermore, in atmospheric waters, $\mathrm{Hg}$ photoreduction is enhanced in the presence of both synthetic iron oxides and ambient particles (43). Further experiments are needed to clarify the role of iron in $\mathrm{Hg}^{0}$ reduction, i.e., to determine whether the pool of photoreducible $\mathrm{Hg}$ is partly formed of iron oxide- bound $\mathrm{Hg}$, or if particulate iron species are indirectly involved in $\mathrm{Hg}$ reduction (e.g., through reactions associated with the photochemical reductive dissolution of solid Fe species).

Alternatively, the decrease of $\Delta_{\mathrm{DGM}}$ in coastal areas upon filtration may implicate microorganisms. However, our dark controls systematically yielded no or low and insignificant DGM production over a $3-5 \mathrm{~h}$ incubation period. Even though we cannot yet offer a definite answer as to the role of microbes in this case, the occurrence of microbially mediated reductive processes is supported by our recent findings that mercury resistance is genetically expressed in coastal Arctic systems (Poulain et al., unpublished). Further research is required to assess and fully understand their role in polar areas. Since our dark controls did not show DGM production over a 3-5 h incubation period, we investigated the possible involvement of photobiological processes.

Role of Photosynthetic Organisms in DGM Production. To test for the influence of algae and photosynthetic microbial mats on $\mathrm{Hg}$ cycling in High Arctic waters, we carried out a series of in situ experiments. In order to simulate natural processes as closely as possible, we used benthic species that were abundant at our sites. Two filamentous chlorophyte species were chosen for incubations: Enteromorpha sp. was used for coastal seawaters and brackish ponds and Ulothrix sp. was used for freshwater incubations. It is most likely that heterotrophic bacteria were also added along with the algae, representing a consortium of algae and bacteria rather than a monospecific mat. Microbial mats, which formed a dense black layer on the bottom of ponds and streams, were also composed of both algae and cyanobacteria. The mats were overwhelmingly dominated by the latter, and these included Nostoc sp., Rivularia sp., Scytonema sp., and Oscillatoria sp. as identified by light and electron microscopy. 
We carried out a series of incubations using either whole cells (Enteromorpha sp., Ulothrix sp., or mats of cyanobacteria) or their exudates, i.e., biogenic compounds derived from Enteromorpha sp. and Ulothrix sp.. When whole cells were added to filtered saltwater pond samples prior to the incubation, $\triangle$ DGM decreased to near zero (Figure 4A). Similarly, when exudates from Enteromorphasp. were added to filtered lagoon water samples prior to incubation, a strong decrease in DGM concentrations was observed compared to the control filtered samples (Figure 3A); DGM photoproduction decreased from 37.0 to $14.4 \mathrm{fmol} \cdot \mathrm{L}$ ${ }^{1} \mathrm{~mol}_{\text {photon }}{ }^{-1} \cdot \mathrm{m}^{2}$.

Upon the addition of whole cells of Ulothrix sp. to filtered fresh pond water (Figure 4B), variations in [DGM] stayed positive and no statistically significant difference was observed between the treatments. Similarly, no significant difference was noted in the production of DGM with or without the addition of either exudates (Figure 3D) or cyanobacterial mats (data not shown). Contrary to what was observed in previous studies $(25,45)$, inhibition of photo- synthesis did not significantly affect $\mathrm{Hg}$ reduction in both fresh and salt waters (Figure 4A and B).

To better understand why the addition of exudates to brackish water decreased $\Delta_{\mathrm{DGM}}$, an experiment was designed to test for the role of exudates in $\mathrm{Hg}$ oxidative processes (Figure 4C). After an initial incubation for $3 \mathrm{~h}$ in sunlight (data not shown), $[D G M]$ increased up to $757 \pm 14 \mathrm{fmol} \cdot \mathrm{L}^{-1}$. After the subsequent addition of exudates, further exposure of the samples to the sun yielded an increase in [DGM] in both samples with or without exudates. However, this increase in [DGM] was less important in the presence of exudates than in the control (Figure 4C). When samples spiked with exudates were kept in the dark, [DGM] greatly decreased by ca. $40 \%$ (corresponding to a decrease of $-72 \mathrm{fmol} \cdot \mathrm{L}^{-1}, \mathrm{~h}^{-1}$ ) and reached a plateau after $3.5 \mathrm{~h}$ (Figure 4C), underscoring the occurrence of dark oxidative processes. When no exudates were added, [DGM] stayed stable under dark conditions. The rate of oxidation, calculated from the decrease over time of [DGM] in the dark, was $0.1 \mathrm{~h}^{-1}$, within the range of previously reported values for salt waters, and ca. 5 to 10 times higher than the rates that have previously been encountered in fresh waters $(17,20,46)$. Smith et al. (47) and Siciliano et al. (27) suggested that $\mathrm{Hg}(0)$ oxidation may be carried out by bacteria using an intracellular catalase and likely coupled to $\mathrm{H}_{2} \mathrm{O}_{2}$ transformations. This internal process seems unlikely in our case, since exudates were very gently filtered through $0.2 \mu \mathrm{m}$ filters and thus most bacteria were removed, although some cell breakage may have occurred. Weidentified several organic moleculesin exudates collected from incubation of
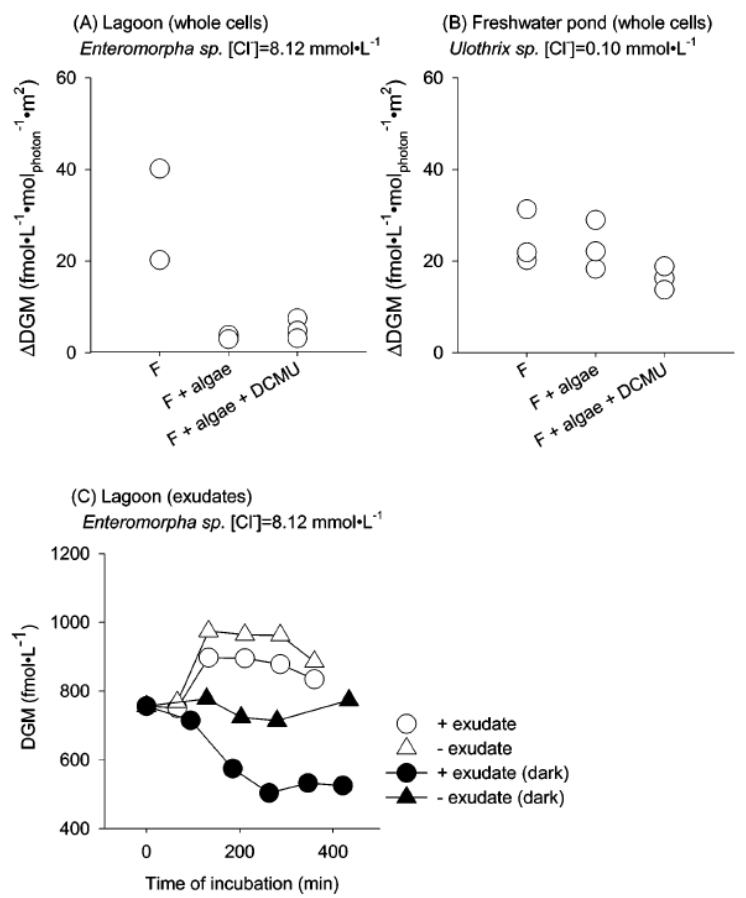

FIGURE 4. DGM production in filtered samples amended or not amended with whole algal cells. (A) Salt water pond amended with microbial consortium comprised of Enteromorpha sp. (note for the controlled filtered (F) treatment $\boldsymbol{n}=\mathbf{2}$ because we lost a sample) and $(B)$ freshwater pond amended with microbial consortium comprised of Ulothrix sp. DCMU refers to treatment where the microbial consortium was treated with an inhibitor of photosynthesis specific to photosystem II. (C) Temporal evolution of newly produced DGM in lagoon samples exposed to natural sunlight (open symbols) and kept in the dark (closed symbols) with the addition of microbial and algae consortium exudates (circles) or without the addition of exudates (triangles). 


\section{https://pubs.acs.org/doi/abs/10.1021/es061980b}

Enteromorpha sp. and Ulothrix sp. using different mass spectrometry techniques to detect molecules with molecular weight equal to or less than $500 \mathrm{Da}\left(1 \mathrm{Da}=1 \mathrm{~g} \bullet \mathrm{mol}^{-1}\right)$. Most of the identified organic molecules contained aromatic rings rather than aliphatic chains (see Table 3A and B in the SI). There were some similarities in identified molecules in both saline and fresh water samples, but some alcohols and aldehydes were only observed in saline water samples. These differences in composition were systematic for several samples. The formation of alcohols and aldehydes often results from oxidative processes and, although they do not constitute a definite proof, these differences in composition suggested a higher oxidative potential for saline water. Note that the SPME technique as it was used in this study does not allow for detection of organic acids, which are expected to be present in highly oxidized environments.

We could not attribute $\mathrm{Hg}(0)$ oxidation observed in salt waters to a single type of biogenic organic material. Rather, the oxidation observed in saline waters was likely the result of either photoinduced processes involving chloride and organic compounds as previously proposed (20) or directly due to the excretion of oxidants. Indeed, it has recently been documented that microorganisms are able to excrete mobile small molecules capable of undergoing multiple redox cycles affecting metals speciation (electron shuttles) (48) and therefore potentially affect $\mathrm{Hg}(0)$ oxidation state.

Our data suggest that biogenic compounds were directly involved in oxidation reactions but that direct incident light was not required. Based on the chemical structure of the organic compounds, the production of a variety of organic intermediates, including radicals, could be expected in the presence of large pools of oxidant precursors (e.g., halides, $\mathrm{NO}_{2}^{-}$, and $\mathrm{NO}_{3}^{-}$); these precursors can release active halogens and $\mathrm{HO}$ radicals upon photolysis. Clearly, a set of reactions can supply oxidants to transform $\mathrm{Hg}(0)$ to $\mathrm{Hg}(\mathrm{II})$, the first phase occurring under sunlit conditions, whereas the reactions can further continue in the dark involving organic compounds and leading eventually to $\operatorname{Hg}(0)$ oxidation. Alternatively, further assessment of the role of electron shuttles in $\mathrm{Hg}$ redox reactions should bring further enlightenment on its overall cycle both in temperate and polar regions.

The results reported here suggest that coastal areas may be more vulnerable to $\mathrm{Hg}$ contamination compared to fresh systems, due to increased $\mathrm{Hg}$ residence time because of enhanced oxidative processes. $\mathrm{Hg}(0)$ oxidation is promoted both by increased salinity and the production of oxidative biogenic exudates. This alteration of $\mathrm{Hg}$ cycle at higher salinity may, however, be counterbalanced by reductive processes likely involving iron particles.

\section{Acknowledgments}

We thank B.E. Keatley for comments on the manuscript as well as those of three anonymous reviewers. We thank the Polar Continental Shelf Project for their outstanding logistic support (this is PCSP contribution 041-06) and the Nunavut Research Institute. We express our gratitude to Dr. H. Vali for access to the electron microscopy facility at McGill University. We thank Paddy Aqiatusuk as well as Debbie Iqaluk for their outstanding help and support in the field. A. Cattaneo, S. Hamelin, and L. Pelletier are acknowledged for their help with algae identification and microscope work, and D. Bélanger is acknowledged for his help in the lab. This project was funded by the Science Horizon Program of Environment Canada; a CFCAS grant to P.A.A. and M.A.; aNSERC COMERN and Discovery grant to P.A.A. and M.A. as well as a FQRNT-Equipe grant to M.A. and P.G.C.C.

\section{Supporting Information Available}

Details on methods, water chemistry of the sampling sites, thermodynamic data used to model $\mathrm{Hg}$ speciation, and organic compounds present in freshwater and saltwater (detected using SPME-GC-MS) This material is available free of charge via the Internet at http://pubs.acs.org.

\section{Literature Cited}

(1) Schroeder, W. H.; Anlauf, K. G.; Barrie, L. A.; Lu, J. Y.; Steffen, A.; Schneeberger, D. R.; Berg, T. Arctic springtime depletion of mercury. Nature 1998, $394,331-332$.

(2) Lindberg, S. E.; Brooks, S.; Lin, C. J.; Scott, K. J.; Landis, M. S.; Stevens, R. K.; Goodsite, M.; Richter, A. Dynamic oxidation of gaseous mercury in the Arctic troposphere at polar sunrise. Environ. Sci. Technol. 2002, 36, 1245-1256.

(3) Ebinghaus, R.; Kock, H. H.; Temme, C.; Einax, J. W.; Lowe, A. G.; Richter, A.; Burrows, J. P.; Schroeder, W. H. Antarctic springtime depletion of atmospheric mercury. Environ. Sci. Technol. 2002, 36, 1238-1244.

(4) Dommergue, A.; Ferrari, C. P.; Poissant, L.; Gauchard, P. A.; Boutron, C. F. Diurnal cycles of gaseous mercury within the snowpack at Kuujjuarapik/Whapmagoostui, Quebec, Canada. Environ. Sci. Technol. 2003, 37, 3289-3297.

(5) Swain, E. B.; Engstrom, D. R.; Brigham, M. E.; Henning, T. A.; Brezonik, P. L. Increasing Rates of Atmospheric Mercury Deposition in Midcontinental North-America. Science 1992, 784-787.

(6) Sprovieri, F.; Pirrone, N.; Landis, M. S.; Stevens, R. K. Oxidation of gaseous elemental mercury to gaseous divalent mercury during 2003 polar sunrise at Ny-Alesund. Environ. Sci. Technol. 2005, 39, 9156-9165.

(7) Ariya, P. A.; Khalizov, A.; Gidas, A. Reactions of gaseous mercury with atomic and molecular halogens: Kinetics, product studies, and atmospheric implications. J. Phys. Chem. A 2002, 106, 7310- 7320.

(8) Ariya, P. A.; Dastoor, A. P.; Amyot, M.; Schroeder, W. H.; Barrie, L.; Anlauf, K.; Raofie, F.; Ryzhkov, A.; Davignon, D.; Lalonde, J.; Steffen, A. The Arctic: a sink for mercury. Tellus, Ser. B 2004, 56, 397-403.

(9) Orihel, D. M.; Paterson, M. J.; Gilmour, C. C.; Bodaly, R. A.; Blanchfield, P. J.; Hintelmann, H.; Harris, R. C.; Rudd, J. W. M. Effect of loading rate on the fate of mercury in littoral mesocosms. Environ. Sci. Technol. 2006, 40, 5992-6000.

(10) Hammerschmidt, C. R.; Fitzgerald, W. F. Methylmercury in freshwater fish linked to atmospheric mercury deposition. Environ. Sci. Technol. 2006, 40 (24), 7764-7770. 


\section{https://pubs.acs.org/doi/abs/10.1021/es061980b}

(11) Muir, D.; Braune, B.; DeMarch, B.; Norstrom, R.; Wagemann, R.; Lockhart, L.; Hargrave, B.; Bright, D.; Addison, R.; Payne, J.; Reimer, K. Spatial and temporal trends and effects of contami- nants in the Canadian Arctic marine ecosystem: a review. Sci. Total Environ. 1999, $230,83-144$.

(12) Van Oostdam, J.; Donaldson, S. G.; Feeley, M.;Arnold, D.;Ayotte, P.; Bondy, G.; Chan, L.; Dewaily, E.; Furgal, C. M.; Kuhnlein, H.; Loring, E.; Muckle, G.; Myles, E.; Receveur, O.; Tracy, B.; Gill, U.; Kalhok, S. Human health implications of environmental contaminants in Arctic Canada: A review. Sci. Total Environ. 2005, 165-246.

(13) Steffen, A.; Schroeder, W.; Bottenheim, J.; Narayan, J.;Fuentes, J.D. Atmospheric mercury concentrations: measurements and profiles near snow and ice surfaces in the Canadian Arctic during Alert 2000 . Atmos. Environ. 2002, 36, 2653-2661.

(14) Douglas, T. A.; Sturm, M.; Simpson, W. R.; Brooks, S.; Lindberg, S. E.; Perovich, D. K. Elevated mercury measured in snow and frost flowers near Arctic sea ice leads. Geophys. Res. Lett. $2005,32$.

(15) Ferrari, C. P.; Gauchard, P. A.; Aspmo, K.; Dommergue, A.; Magand, O.; Bahlmann, E.; Nagorski, S.; Temme, C.; Ebinghaus, R.; Steffen, A.; Banic, C.; Berg, T.; Planchon, F.; Barbante, C.; Cescon, P.; Boutron, C. F. Snow-to-air exchanges of mercury in an Arctic seasonal snow pack in Ny-Alesund, Svalbard. Atmos. Environ. 2005, 39, 7633-7645.

(16) Fain, X.; Ferrari, C. P.; Gauchard, P. A.; Magand, O.; Boutron, C. Fast depletion of gaseous elemental mercury in the Kongs- vegen Glacier snowpack in Svalbard. Geophys. Res. Lett. $2006,33$.

(17) Amyot, M.; Gill, G. A.; Morel, F. M. M. Production and loss of dissolved gaseous mercury in coastal seawater. Environ. Sci. Technol. 1997, 31, 3606-3611.

(18) Tseng, C. M.; Lamborg, C.; Fitzgerald, W. F.; Engstrom, D. R. Cycling of dissolved elemental mercury in Arctic Alaskan lakes. Geochim. Cosmochim. Acta 2004, 68, 1173-1184.

(19) Aspmo, K.; Temme, C.; Berg, T.; Ferrari, C. P.; Gauchard, P. A.; Fain, X.; Wibetoe, G. Mercury in the Atmosphere, Snow and Melt Water Ponds in the North Atlantic Ocean during Arctic Summer. Enivron. Sci. Technol. 2006, 40, 4083-4089.

(20) Lalonde, J. D.; Amyot, M.; Kraepiel, A. M. L.; Morel, F. M. M. Photooxidation of Hg(0) in artificial and natural waters. Environ. Sci. Technol. 2001, 35, 1367-1372.

(21) Whalin, L. M.; Mason, R. P. A new method for the investigation of mercury redoxchemistry in natural waters utilizing deflatable Teflon (R) bags and additions of isotopically labeled mercury. Anal. Chim. Acta 2006, 558, 211-221.

(22) Dommergue, A.; Ferrari, C. P.; Gauchard, P. A.; Boutron, C. F.; Poissant, L.; Pilote, M.; Jitaru,P.; Adams, F.C. Thefate of mercury species in a sub-arctic snowpack during snowmelt. Geophys. Res. Lett. 2003, 30.

(23) Amyot, M.; Lean, D.; Mierle, G. Photochemical formation of volatile mercury in high Arctic lakes. Environ. Toxicol. Chem. 1997, 16, 2054-2063.

(24) Barkay, T.; Liebert, C.; Gillman, M. Environmental Significance of the Potential for Mer(Tn21)-Mediated Reduction of Hg-2+ to Hg-0 in NaturalWaters. Appl. Environ. Microbiol. 1989, 55, 1196-1202.

(25) Mason, R. P.; Morel, F. M. M.; Hemond, H. F. The Role of Microorganisms in Elemental Mercury Formation in Natural- Waters. Water, Air Soil Pollut. 1995, 80, 775-787

(26) Lanzillotta, E.; Ceccarini, C.; Ferrara, R.; Dini, E.; Frontini, E.; Banchetti, R. Importance of the biogenic organic matter in photo-formation of dissolved gaseous mercury in a culture of the marine diatom Chaetoceros sp. Sci. Total Environ. 2004, 318, $211-221$.

(27) Siciliano, S. D.; O’Driscoll, N. J.; Lean, D. R. Microbial reduction and oxidation of mercury in freshwater lakes. Environ. Sci. Technol. 2002, 36, 3064-3068.

(28) O’Driscoll, N. J.; Siciliano, S. D.; Lean, D. R. S.; Amyot, M. Gross photoreduction kinetics of mercury in temperate freshwater lakes and rivers: Application to a general model of DGM dynamics. Environ. Sci. Technol. 2006, 40, 837-843.

(29) Gill, G. A.; Bruland, K. W. Mercury Speciation in Surface Fresh- Water Systems in California and Other Areas. Environ. Sci. Technol. 1990, 24, $1392-1400$

(30) Schecher, W. D.; McAvoy, D. C. Mineql+ - a Software Environ- ment for Chemical-Equilibrium Modeling. Comp. Environ. Urban Syst. 1992, 16, $65-76$.

(31) Rolfhus, K. R.; Fitzgerald, W.F. Theevasionandspatial/temporal distribution of mercury species in Long Island Sound, CT-NY. Geochim. Cosmochim. Acta 2001, 65, 407-418.

(32) Ravichandran, M. Interactions between mercury and dissolved organic matter - a review. Chemosphere 2004, 55, 319-331.

(33) Amyot, M.; Mierle, G.; Lean, D. R. S.; McQueen, D. J. Sunlight- Induced Formation of Dissolved Gaseous Mercury in Lake Waters. Environ. Sci. Technol. 1994, 28, 2366-2371.

(34) Garcia, E.; Amyot, M.; Ariya, P. A. Relationship between DOC photochemistry and mercury redox transformations in temper- ate lakes and wetlands. Geochim. Cosmochim. Acta 2005, 69, 1917-1924.

(35) O'Driscoll, N. J.; Lean, D. R. S.; Loseto, L. L.; Carignan, R.; Siciliano, S. D. Effect of dissolved organic carbon on the photoproduction of dissolved gaseous mercury in lakes: Po- tential impacts of forestry. Environ. Sci. Technol. 2004, 38, 2664- 2672.

(36) Lu, J. Y.; Schroeder, W. H.; Barrie, L. A.; Steffen, A.; Welch, H. E.; Martin, K.; Lockhart, L.; Hunt, R. V.; Boila, G.; Richter, A. Magnification of atmospheric mercury deposition to polar regions in springtime: the link to tropospheric ozone depletion chemistry. Geophys. Res. Lett. 2001, 28, 3219-3222.

(37) Lalonde, J. D.; Amyot, M.; Orvoine, J.; Morel, F. M. M.; Auclair, J. C.; Ariya, P. A. Photoinduced oxidation of Hg-0 (aq) in the waters from the St. Lawrence estuary. Environ. Sci. Technol. 2004, 38, 508-514.

(38) Gardfeldt, K.; Jonsson, M. Is bimolecular reduction of $\mathrm{Hg}(\mathrm{II})$ complexes possible in aqueous systems of environmental importance? J. Phys. Chem. A 2003, 107, 4478-4482.

(39) Gardfeldt, K.; Feng, X. B.; Sommar, J.; Lindqvist, O. Total gaseous mercury exchange between air and water at river and sea surfaces in Swedish coastal regions. Atmos. Environ. 2001, 35, 3027-3038.

(40) Nriagu, J.O. MechanisticSteps in the Photoreduction ofMercury in Natural-Waters. Sci. Total Environ. $1994,154,1-8$.

(41) Emmenegger, L.; Schonenberger, R. R.; Sigg, L.; Sulzberger, B. Light-induced redox cycling of iron in circumneutral lakes. Limnol. Oceanogr. 2001, 46, 49-61.

(42) Zhang, H.; Lindberg, S. E. Sunlight and iron(III)-induced photochemical production of dissolved gaseous mercury in freshwater. Environ. Sci. Technol. 2001, 35, 928-935.

(43) Lin, C. J.; Pehkonen, S. O. Aqueous free radical chemistry of mercury in the presence of iron oxides and ambient aerosol. Atmos. Environ. 1997, 31, 4125-4137.

(44) Stumm, W.; Morgan, J. J.Aquatic Chemistry; Chemical Equilibria and Rates in Natural Waters; Wiley Interscience; John Wiley \& Sons Inc.: 
https://pubs.acs.org/doi/abs/10.1021/es061980b

New York, 1996.

(45) Poulain, A. J.; Amyot, M.; Findlay, D.; Telor, S.; Barkay, T.; Hintelmann, H. Biological and photochemical production of dissolved gaseous mercury in a boreal lake. Limnol. Oceanogr. 2004, 49, 2265-2275.

(46) Garcia, E.; Poulain, A. J.; Amyot, M.; Ariya, P. A. Diel variations in photoinduced oxidation of Hg-0 in freshwater. Chemosphere 2005, 59, 977981.

(47) Smith, T.; Pitts, K.; McGarvey, J. A.; Summers, A. O. Bacterial oxidation of mercury metal vapor, Hg(0). Appl. Environ. Microbiol. 1998, 64, 13281332.

(48) Hernandez, M.E.; Newman, D. K. Extracellular electron transfer.

(49) Cell. Mol. Life Sci. 2001, 58, 1562-1571 